\title{
Pengaruh Kreativitas Guru Terhadap Minat Belajar Siswa Tema 1 Diriku Kelas I SDN Randegan Kec.Tanggulangin Kab. Sidoarjo
}

\author{
${ }^{1}$ Anita Risky Trisnowati, ${ }^{2}$ Endang Wahju Andjariani \\ ${ }^{12}$ Pendidikan Guru Sekolah Dasar, STKIP PGRI Sidoarjo \\ Email: ${ }^{1}$ risky.anita65@gmail.com, ${ }^{2}$ endang.wahyu1818@gmail.com
}

\begin{abstract}
The purpose of the research that the author did was to find out how the teacher's creativity and student interest in learning on theme 1, both from the advantages and disadvantages of interest in learning in grade 1 students at SDN Randegan Tanggulangin Sidoarjo. In this research process using a questionnaire method and interviews with grade 1 students of SDN Randegan, totaling 7 students / respondents. This research cannot be done in the school area due to the COVID 19 pandemic. The results of quantitative research obtained data on the efficiency of determination of $66,1 \%$ of the influence of teacher creativity on student interest in learning. With a remaining amount of 33,9\% from other factors. From the results of the regression equation carried out, the data obtained is $\mathrm{Y}=35,420+0,511 \mathrm{X}$. from the regression equation results, student interest in learning will increase by 0,511 times along with teacher creativity.
\end{abstract}

\section{Keywords: Teacher Creativity, Learning Interest}

Abstrak. Tujuan dari penelitian yang penulis lakukan untuk mengetahui bagaimana kreativitas guru dan minat belajar siswa pada tema 1, baik dari kelebihan serta kekurangan dalam minat belajar pada siswa kelas 1 di SDN Randegan Tanggulangin Sidoarjo. Pada proses penelitian ini menggunakan metode angket dan wawancara kepada siswa kelas 1 SDN Randegan yang berjumlah 7 siswa/responden. Penelitian ini tidak bisa dilakukakn di area sekolah dikarenakan pandemic COVID-19. Hasil dari penelitian kuantitatif yang dilakukakan memperoleh data koefisien determinasi sejumlah $66,1 \%$ dari pengaruh kreativitas guru terhadap minat belajar siswa, dan jumlah sisa 33,9\% dari faktor lainnya. Dari hasil persamaan regrensi yang dilakukan memperoleh data $\mathrm{Y}=35,420+0,511 \mathrm{X}$ dari hasil persamaan regresi minat belajar siswa akan meningkat sebesar 0,511 kali seiring dengan kreativitas guru.

\section{Kata Kunci : Kreativitas Guru, Minat Belajar}

\section{PENDAHULUAN}

Pendidikan merupakan salah satu usaha manusia yang dilakukan dengan sadar untuk membentuk suatu kepribadian agar menjadi bijak, semula belum memiliki pengetahuan menjadi lebih tahu akan hal-hal baru. Sehingga bisa terbentuk kepribadian tersebut membutuhkan waktu yang cukup lama.

Bentuk pendidikan di Indonesia terdiri dari pendidikan formal dan nonformal. Pendidikan adalah salah satu usaha untuk terwujudnya suasana belajar yang baik, agar siswa mampu bersikap aktif dan mampu memperkaya potensi diri, berakhlakul karimah, memiliki kecerdasan psikologis yang bagus atau dapat mengendalikan dirinya serta berguna bagi bangsa dan negara (Kemendiknas, 2003:2).

Pendidikan memiliki unsur - unsur yang salah satu unsurnya adalah Guru. Guru adalah seseorang yang terlibat dalam proses pembelajaran dan ikut serta berperan penting dalam proses pembangunan kualitas SDM di Indonesia. Guru merupakan salah satu unsur di bidang pendidikan yang ikut berperan aktif. Guru juga harus bisa menjadi seorang pendidik yang professional dan harus mampu mengikuti kemajuan zaman dan teknologi.

Minat juga sangat berpengaruh terhadap pola belajar, jika siswa tidak memiliki minat belajar, siswa tidak akan mampu untuk belajar dengan sungguh sungguh, karena jika siswa tidak memiliki 
minat siswa tidak tertarik pada pembelajaran yang ia pelajari. Jika siswa mempunyai minat maka siswa tersebut akan lebih tertarik untuk belajar, karena siswa mempunyai rasa ketertarikan pada suatu pembelajaran. Observasi awal yang dilakukan peneliti pada bulan September 2020 di Kelas I SD Negeri Randegan Kec. Tanggulangin Kab. Sidoarjo Tahun Pelajaran 2020/2021, sehubungan dengan Pandemi COVID 19 maka proses pembelajaran dilakukan secara berkelompok yang berjumlah 6-7 siswa di rumah salah satu siswa. Ketika peneliti telah melakukan observasi awal maka dapat disimpulkan ada beberapa penghambat minat belajar siswa kelas 1.

Guru dalam suatu proses pembelajaran, guru dituntut untuk dapat melakukan pembelajaran yang inovatif dan kreatif. Guru bisa dikatakan inovatif apabila guru dalam suatu proses pembelajaran dapat melakukan pendekatan - pendekatan agar siswa mampu lebih aktif dibandingkan dengan guru. Pembelajaran dilakukan dengan model-model pembelajaran yang inovatif dan kreatif, pembelajaran yang kreatif dan harus kontekstual (pembelajaran dengan benda nyata), contoh dalam pembelajaran kontekstual yaitu : Apabila siswa menulis pensil maka guru harus menunjukkan pensil dengan benda nyata agar siswa memahami bentuk pensil yang sebenarnya. Evaluasi pembelajaran yang diharapkan dari proses pembelajaran adalah kognitif (pengetahuan), afektif (sikap), dan psikomotor (keterampilan).

Guru berperan penting dalam proses pembelajaran didalam kelas, yang berpengaruh pada minat belajar siswa. Kreativitas guru sangat diperlukan dalam proses pembelajaran didalam kelas agar siswa mempunyai minat belajar yang tinggi ketika berada di sekolah. Maka dari itu, kreativitas guru merupakan komponen penting dalam suatu proses pembelajaran di sekolah, dimana guru dapat mempengaruhi siswa dengan menggunakan tindakan atau perilaku terhadap masingmasing siswa yang dipengaruhi. Upaya untuk mencapai tujuan pembelajaran tidak lepas dari kreativitas guru. Maka dari itu kreativitas guru sangat dibutuhkan dalam proses pembelajaran di sekolah.

Terdapat faktor - faktor yang dapat mempengaruhi minat belajar siswa yaitu kreativitas guru. Ada beberapa mendapat tentang kreativitas guru. WJS. Poerwadarminta (2005 : 526) berpendapat bahwa kreativitas guru adalah manusia yang miliki daya cipta, kreativitas sangat berhubungan dengan suatu penemuan dan dapat menghasilkan sesuatu yang baru. Henowo (2007:71) kreativitas merupakan proses penciptaan sesuatu dari yang belum ada menjadi ada. Tomi Buzan (2003:4) berpendapat bahwa kreativitas merupakan suatu kemampuan dengan memunculkan ide - ide yang baru untuk bisa menyesaikan dengan caranya sendiri agar bisa meningkatkan imajinasi, perilaku dan produktivitas.

Wijaya (1991:198) mengemukakan bahwa kreativitas adalah suatu proses mental yang melibatkan munculnya gagasan atau ide yang bertujuan untuk membangkitkan kreativitas belajar mandiri maupun bekerja sama.

Penggunaan

model-model pembelajaran kreatif dan inovatif juga dapat mempengaruhi minat belajar siswa. Model model pembelajaran yang di sampaikan guru kepada siswa secara karakteristik dan efektif dapat mempengaruhi suatu proses pembelajaran. Guru yang menggunkan model pembelajaran kreatif dan inovatif berdampak langsung terhadap respon siswa baik secara respon positif atau negatif. Penggunaan model secara tepat dan bervariasi, diharapkan dapat menstimulus dan menumbuhkan minat belajar siswa dan menciptakan interaksi antar siswa dengan guru, agar siswa bisa memilih minatnya masing-masing dan kemampuan belajar siswa dapat meningkat.

Di era pandemi sesuai dengan kebijakan pemerintah untuk melaksakan sekolah online. Guru diharapkan tidak monoton dalam mengajar agar siswa senantiasa memperhatikan gurunya sehingga tidak merasa bosan belajar online. Peran orang tua juga sangat dibutuhkan dalam pembelajaran online. Agar menumbuhkan minat belajar pada siswa. 
Observasi awal yang peneliti telah lakukan yakni tentang masalah kurangnya minat belajar siswa. Atas dasar faktor tersebut, peneliti memilih untuk melakukan suatu penelitian dengan judul "Pengaruh Kreativitas Guru Terhadap Minat Belajar Siswa di Kelas I SDN Randegan Tahun Pelajaran 2020 - 2021"

Secara umum bagaimana Kreativitas Guru Dalam Mengajar di SDN Randengan Kec. Tanggulangin?

1. Secara umum bagaimana Minat Belajar Siswa Kelas I di SDN Randegan Kec. Tanggulangin?

2. Secara umum bagaimana ada Pengaruh Kreativitas Guru Dalam Mengajar Terhadap Minat Belajar Siswa Kelas I di SDN Randegan Kec. Tanggulangin ?

\section{METODE PENELITIAN}

Penelitian ini menggunakan jenis deskriptif kuantitatif. Penelitian yang menggunakan proses pengambilan data-data yang berupa angka sebagai alat menganalisis dan melakukan kajian penelitian. Bentuk data kuantitatif yaitu angka atau bisa juga berasal dari data kualitatif yang diubah dalam bentuk angka. Contoh dari data kuantitatif adalah data yang terdapat skala pengukuran. Dalam penelitian ini peneliti menggunakan data berupa angket yang terdapat pernyataan/ pertanyaan dan alternatif jawaban. Alternatif jawaban antara lain (4) Selalu, (3) Sering, (2) Jarang (1) Tidak Pernah. Penelitian di laksanakan secara offline karena sumber data dapat di ambil lebih mudah di era pandemi covid-19 peneliti dapat menerapkan protokol kesehatan karena hanya membutuhkan 7 orang yang di analisis.

Pada penelitian kuantitatif memerlukan 2 variabel, yang terdiri dari (1) Variabel Bebas (Independent Variable) (2) Variabel terikat (Dependent Variable). Variabel Bebas (Independent Variable) adalah variabel $\mathrm{X}$ atau variabel yang mempengaruhi suatu proses penelitian yang menjadi variabel bebas dalam penelitian ini adalah kreativitas guru, sedangkan variabel terikat (Dependent Variable) adalah variabel $\mathrm{Y}$ atau variabel yang terlibat pengaruh, dalam penelitian ini yang menjadi variabel bebas adalah Minat Belajar.
Teknik pengumpulan data Teknik yang digunakan yaitu Penelitian lapangan/observasi (field research) penelitian ini bersifat kuantitiatif. Pada penelitian ini peneliti menggunakan pengambilam data dari berbagai sumber (1) Angket (2) Dokumentasi (3) Observasi (4) Interview/wawancara. Teknik Analisa Data yang digunakan menggunakan metode yang digunakan dalam penelitian ini adalah analisa kuantitatif yaitu suatu kumpulan dari keterangan - keterangan dalam hal ini peneliti menggunakan angket, sedangkan untuk menganalisa data angket tersebut peneliti menggunakan beberapa tahapan diantaranya : (1) Analisis Pendahuluan (2) Analisis Uji Hipotesis (3) Analisis lanjut

Pada penelitian ini menggunakan instrumen penelitian berupa angket yang dimana terdapat suatu pertanyaan/pernyataan tentang kreativitas guru dan minat belajar ,dan untuk memperoleh data tentang minat belajar juga peneliti masih menggunakan angket. Instrumen pada penelitian ini menggunakan angket dengan alternatif jawaban sehingga siswa/responden dapat lebih mudah untuk bisa menjawab pertanyaan/pernyataan di angket tersebut. Untuk alternatif jawaban pada angket terdapat 4 jawaban/skor.

Penetapan skor juga tergantung dari jawaban respon baik secara positif maupun secara negatif. Setiap pertanyaan/pernyataan pada angket berjumlah 4 skor dengan urutan skor dari penagruh positif ke pengaruh negatif. sedangkan untuk hasil belajar siswa kelas 1 SDN Randegan Tangulangin Sidoarjo diambil dari nilai rata-rata ulangan harian yang dilakukan siswa.

\section{HASIL DAN PEMBAHASAN}

Pada penelitian ini menggunakan rumus regresi sederhana. Persamaan regresi yang terbentuk yaitu $\mathrm{Y}=35,420+0,511 \mathrm{X}$ jadi minat belajar siswa akan meningkat seiring dengan meningkatnya kreativitas guru kelas 1 dalam pembelajaran sebanyak 0,511 kali.

Berdasarkan uji t, diketahui nilai thitung sebesar 4,418 dengan nilai ttabel sebesar 2,228. Disimpulkan, Ho ditolak dan 
Ha diterima yang berarti variabel X1 berpengaruh parsial terhadap variabel Y.

Diketahui hasil koefisien determinasi $\left(\mathrm{R}^{2}\right)$ pada penelitian ini sebesar 0,661 atau jika dipersentasekan 66,1\%. Artinya, variabel kreativitas guru berpengaruh $66,1 \%$, sisanya $33,9 \%$ dipengaruhi variabel yang ada diluar penelitian.

\section{SARAN}

1. Bagi siswa

a. Diharapkan siswa lebih aktif daripada guru dan siswa harus semangat belajar sehingga bisa menjadi siswa berprestasi.

b. Jangan pernah sekali-kali merasa bosan ketika guru menjelaskan suatu pelajaran

2. Bagi Guru SDN Randegan

a. Untuk lebih ditingkat kreativitas agar proses pembelajaran sangat menyenangkan bagi siswa.

b. Lebih ditingkatkan untuk interaksi dengan siswa agar siswa lebih giat dalam proses belajar.

c. Buatlah proses pembelajaran dengan metode-metode yang menarik agar siswa tidak bosan dengan pembelajaran

\section{DAFTAR PUSTAKA}

Cece, Wijaya. 1991. Upaya Pebaruhan dan Pengajaran. Bandung : Remaja Rosda Karya

Henowo. 2007. Menjadi Guru yang mau dan Mampu Mengajar Secara Kreatif. Bandung : MLC

Tomi Buzan. 2003. Sepuluh Cara Jadi Orang Yang Jenius Kreatif. Jakarta : PT. Gramedia Pustaka Utama

WJS. Poerwadarminta. 2005. Kamus Umum Bahasa Indonesia. Jakarta : Balai Pustaka 